\title{
PENINGKATAN KECERDASAN INTERPERSONAL MELALUI PERMAINAN TRADISIONAL PADA ANAK KELOMPOK B
}

\author{
Widayati \\ Jurusan Pendidikan Guru Pendidikan Anak Usia Dini, Fakultas Ilmu Pendidikan \\ Universitas Trunojoyo Madura \\ email: wie.paud@gmail.com
}

\begin{abstract}
Abstrak: Peningkatan Kecerdasaan Interpersonal Melalui Permainan Tradisional Pada Anak Kelompok B. Penelitian ini bertujuan untuk meningkatkan kecerdasan intrapersonal anak usia dini melalui kegiatan permainan tradisional. Penelitian ini dilakukan di TK Mardi Putra 03 Desa Sumber Brantas, Kota Batu-Malang. Metode yang digunakan adalah metode tindakan kelas. Penelitian ini menggunakan metode penelitian mengacu pada desain model Kurt Lewin. Hasil penelitian menunjukkan bahwa kecerdasan intrapersonal anak setelah mengalami tindakan terjadi peningkatan. pada prasiklus hasil prosentase pembelajaran anak berada pada angka 38,9\%, kemudian pada siklus satu penelitian terjadi peningkatan yang cukup signifikan yaitu $61,24 \%$ dan pada siklus dua terjadi peningkatan sebesar $82.13 \%$.
\end{abstract}

Kata kunci: Kecerdasan Intrapersonal, Permainan Tradisional, Anak Usia Dini

Abstract: Increasing Interpersonal Intelligence Through Traditional Games In Children Group B.This study aims to improve early childhood entrapersonal intelligence through traditional games. This reseach was do in TK Mardi Putra 03 Desa Sumber Brantas, Kota BatuMalang. This research used actiob reseacrh. Data analysis used Kurt Lewin design. The result of the research shows was childrens's intrapersonal intelligencesthrough traditional games could increasi of grade B oinderganten. The end of result of the overall analysis data was the precentage increase wich showed from pre-intervency class average is $38,9 \%$ up to $82,13 \%$ at posttest result.

Keywords: Intrapersonal Intelligence, Traditional Games, Early Childhood 
Pendidikan anak usia dini merupakan awal bagi pertumbuhan dan perkembangan anak. Pendidikan anak usia dini dilakukan melalui pemberian stimulus untuk membantu proses pertumbuhan dan perkembangan agar tercapai secara optimal dan anak siap untuk memasuki pendidikan lebih lanjut. Pendidikan anak usia dini merupakan salah satu bentuk penyelenggaraan pendidikan yang menitik beratkan pada peletakan dasar ke arah pertumbuhan dan perkembangan fisik-motorik, bahasa, kognitif serta sosial emosional sesuai dengan karakteristik anak usia dini yaitu memperhatikan anak sebagai individu yang unik, menyesuaikan dengan lingkungan dan tahapan perkembangan anak. Hal ini cukup penting mengingat anak merupakan generasi penerus di masa depan. Anak merupakan sumber daya manusia yang sangat menentukan kemajuan sebuah negara di masa yang akan datang, oleh karena itu persiapan pengembangan sumber daya manusia haruslah tepat khususnya sejak anak usia dini.

Persiapan pengembangan sumber daya manusia sejak usia dini cenderung memiliki keberhasilan di masa mendatang dengan baik. Salah satu aspek yang dapat mempengaruhi keberhasilan anak dimasa yang akan datang adalah aspek kecerdasan intrapersonal. Pengembangan kecerdasan interpersonal anak usia 6-7 tahun sangatlah penting. Pendidik anak usia dini memiliki peran yang cukup besar dalam perkembangan kecerdasan anak, karena kecerdasan anak dibentuk melalui proses kegiatan pembelajaran sehari-hari yang dilakukan oleh pendidik dan anak. Kecerdasan intrapersonal dinilai memegang peran penting dalam menentukan keberhasilan anak di masa yang akan datang karena kecerdasan intrapersonal mengkaji tentang kapasitas seorang individu mengenali dan memahami perasaan yang terjadi pada dirinya. Pendapat lain menyatakan kecerdasan intrapersonal adalah pengetahuan tentang diri sendiri dan kemampuan untuk bertindak secara adaptif atas dasar pengetahuan (Amstrong, 2009:7). Artinya keberhasilan anak pada tahap selanjutnya sangatlah ditentukan dengan kemampuan anak dalam memanage emosi diri sendiri, sikap dan tingkah laku, oleh karena itu kecerdasan intrapersonal harusnya mendapat perhatian yang utama untuk dikembangkan dalam proses kegiatan pembelajaran.

Pada kenyataanya ditemukan kondisi bahwa guru dalam praktik pendidikan tidak mengedepankan pentingnya stimulasi kecerdasan intrapersonal anak usia dini. Hal ini diketahui berdasarkan hasil observasi awal yang dilakukan di TK Mardi putra 3, desa Sumber Brantas Kota Batu-Malang. Hasil observasi diketahui bahwa pada saat proses kegiatan pembelajaran, guru cenderung hanya memperhatikan kemajuan anak dalam aspek membaca, menulis dan berhitung. Hasil wawancara awal yang dilakukan juga diketahui bahwa orientasi kegiatan pembelajaran hanya bertumpu pada bagaimana langkah-langkah dan strategi agar anak bisa membaca dan menulis serta berhitung. Kemajuan dalam aspek membaca, menulis dan berhitung menjadi target utama tujuan pembelajaran sehari-harinya.

Orentasi kegiatan pembelajaran yang hanya bertumpu pada aspek membaca, menulis dan berhitung tentunya sangat berpengaruh terhadap kecerdasan intrapersonal anak. Setelah diambil data awal diketahui bahwa dari jumlah 15 anak pada kelompok B, aspek mengenal perasaan diri sendiri anak lemah dan hal ini terjadi pada 15 anak, mengenal kemampuan dan kelemahan diri sendiri dari 15 anak, 8 diantaranya masih rendah, bersikap realistis terhadap kelemahan dan kelebihan diri sendiri dari 15 anak, 10 anak rendah, berfikir reflektif dan mengekspresikan perasaan dari 15, 9 anak cukup rendah, skor rendah juga terlihat pada aspek kemampuan anak dalam melihat perbedaan dan persamaan dirinya dengan orang lain, pada aspek ini hampir semua anak mendapat skor yang cukup rendah.

Anak lemah dalam mengidentifikasi emosi diri sendiri seperti menyatakan bahwa 
mereka senang, sedih, belum berani menentukan kegiatan apa yang dilakukan sendiri, belum paham untuk menerima kekurangan dan kelebihan diri sendiri, belum begitu terlihat pengalihan pemikiran imajinatif pada kenyataan, kemampuan untuk melakukan sesuatu kegiatan masih belum nampak, kemampuan memandang dunia dari sudut diri sendiri masih rendah dan mengontrol perilaku diri sendiripun juga masih rendah. Pada saat mengontrol perilaku diri sendiri anak cenderung selalu melihat respon orang lain, anak tidak berani memutuskan saya akan bermain apa, dengan siapa dan permainan yang bagaimana.

Berdasarkan permasalahan di atas maka peneliti ingin membuat sebuah studi yang bertujuan untuk meningkatkan kecerdasan intrapesronal melalui permainan tradisional. Permainan tradisional dipilih dikarenakan dunia anak adalah dunia bermain dan pada saat melakukan aktivitas bermain, anak dapat mengeksplor setiap aspek perkembangannya, anak dapat mengenali dunia sekitarnya, dan anak dapat berlatih bagaimana bersosialisasi dengan lingkungan melalui aktivitas bermain (Sujiono, 2011:6).

\section{Anak Usia Dini}

Anak usia dini merupakan masa yang paling penting bagi perkembangan anak sehingga anak usia dini sedang dalam tahap pertumbuhan dan perkembangan yang paling pesat baik fisik maupun mental, perkembangan otak sebagai pusat kecerdasaan terjadi sangat cepat karena perkembangan otak pada anak usia dini telah mencapai 80 prosen dari orang dewasa sehingga masa itu disebut sebagai golden age. Menurut penelitian di bidang neurosains yang dilakukan oleh Osbon, White dan Bloom sebagaimana dikutip Suyadi menyatakan bahwa perkembangan kecerdasaan atau intelektual anak pada usia empat tahun mencapai 50 prosen, pada usia delapan tahun mencapai 80 prosen, pada usia dua belas tahun mencapai 90 prosen, dan pada usia delapan belas tahun perkembangan intelektual anak mencapai 100 prosen atau telah mencapai perkembangan yang optimal (Suyadi, 2014:33). Dalam hal ini periode perkembangan kecerdasan anak akan meningkat seiring bertambahnya usia anak hingga anak masuk dalam fase dewasa muda. Senada dengan itu dalam kerangka pelaksanaan pendidikan anak usia dini, Undang-undang Nomor 20 tahun 2003 tentang Sisdiknas pasal 28 ayat 1 mengatakan bahwa anak usia dini adalah anak yang berada pada rentang usia sejak lahir sampai dengan enam tahun. Jadi berdasarkan system pendidikan nasional di Indonesia, anak usia dini merupakan anak yang memiliki usia sejak lahir sampai dengan enam tahun. Menurut NAEYC (National Assosiation Education for Young Children) mengemukakan bahwa anak usia dini adalah sekelompok individu yang berada pada rentang usia antara nol sampai delapan tahun (Hartati, 2007:10). Pada periode perkembangan anak usia dini 0-8 tahun, merupakan tahapan perkembangan yang sangat unik seperti pemerolehan bahasa pertama dan lain sebagainya. Hal ini menunjukan bahwa perkembangan anak yang memerlukan perhatian khusus untuk dikembangkan di periode keemasaan ini. Hal ini sejalan dengan pendapat Soegeng Santoso sebagaimana dikutip oleh Ramli mengatakan bahwa anak usia dini ialah anak yang berada pada rentang masa usia lahir sampai usia delapan tahun (Ramli, 2004:1). Sekelompok anak yang yang rentang usia lahir sampai delapan tahun yang memiliki berbagai potensi yang siap dikembangkan melalui pemberian rangsangan. Jadi menurut NAEYC dan Santoso, anak usia dini merupakan anak yang berada pada rentang usia nol sampai delapan tahun.

Hartati mengemukakan bahwa anak usia dini merupakan kelompok manusia yang berada dalam proses pertumbuhan dan perkembangan secara terus menerus (Hartati, 2007:11). Hal ini menandakan bahwa anak usia dini adalah individu yang unik dimana anak memiliki pola pertumbuhan dan perkembangan fisik, kognitif, sosio-emosional, 
kreativitas, bahasa dan komunikasi. Dari beberapa definisi tentang anak usia dini di atas dapat disimpulkan bahwa anak usia dini adalah anak yang berada pada rentang umur nol sampai delapan tahun yang memiliki sifat yang unik, sehingga pada masa anak usia dini baik diberikan stimulasi perkembangan dengan melalui pemberian pendidikan untuk membantu pertumbuhan dan perkembangan jasmani dan rohani, pembinaannya diselenggarakan secara terpadu dalam satu program pembelajaran agar anak dapat mengembangkan segala daya guna dan kreatifitasnya sesuai dengan karakteristik perkembangannya dan memiliki kesiapan untuk jenjang pendidikan selanjutnya.

\section{Kecerdasan Intrapersonal}

Kecerdasan intrapersonal adalah sebagai suatu kemampuan untuk mengenal perasaan-perasaan yang ada pada diri sendiri, seperti perasaan senang ataupun sedih (Gardner, 1993:239). Kecerdasan intrapersonal mengkaji tentang kapasitas seorang individu mengenali dan memahami perasaan yang terjadi pada dirinya. Pendapat lain menyatakan kecerdasan intrapersonal adalah pengetahuan tentang diri sendiri dan kemampuan untuk bertindak secara adaptif atas dasar pengetahuan (Amstrong, 2009:7). Kecerdasan ini termasuk memiliki gambaran yang akurat tentang diri sendiri (kekuatan seseorang dan keterbatasan), kesadaran suasana hati, batin, niat, motivasi, tempramen dan keinginan.

Kecerdasan intrapersonal berkaitan erat dengan aspek internal dalam diri seseorang seperti perasaan hidup, rentang emosi, kemampuan untuk membedakan emosiemosi, menandainya, dan menggunakan untuk memahami dan membimbing tingkah laku sendiri (Musfiroh, 2008:56). Jadi, kecerdasan interpersonal merupakan kemampuan seseorang yang berasal dari dalam diri sendiri dalam mengontrol, memahami, mengenal serta membedakan perasaan dan emosi yang akan berdampak pada tingkah laku seseorang. Berdasarkan penjelasan tersebut dapat diketahui bahwa kecerdasan interpersonal memiliki keterkaitan terhadap penerimaan seseorang dalam lingkungan sosial yang lebih luas. Seseorang bisa diterima dengan baik dalam lingkungan sosial jika dia dapat mengontrol emosi dan sikapnya dan menyesuaikan dengan kultur atau normanorma yang berlaku di masyarakat. Hal ini sesuai dengan pendapat Hoerr yang menyatakan bahwa kecerdasan intrapersonal merupakan kunci (Hoerr, 2007:114). Kecerdasan intrapersonal yang kuat menempatkan kita dalam kesuksesan dalam berbagai aspek, misalkan: karir, pendidikan dan sebagainya.

\section{Permainan Tradisional}

Bermain merupakan sarana yang memungkinkan anak berkembang secara maksimal. Bermain dapat mempengaruhi perkembangan anak dan memberikan kesempatan bagi anak untuk belajar tentang dirinya sendiri, orang lain dan lingkungan. Sebuah pendapat menyatakan bermain juga memberikan kesempatan bagi anak untuk berimajinasi dan bereksplorasi dan menciptakan sesuatu (Carron \& Jan, 1992:21). Menurut Brunner bermain adalah kegiatan yang serius dan merupakan kegiatan pokok dalam masa kanak-kanak. Mayesky menyatakan bagi anak-anak bermain adalah hal yang mereka lakukan sepanjang hari karena hidupnya adalah bermain (Mayesky, 1990: 196). Berdasarkan pernyataan di atas dapat diambil kesimpulan bahwa bermain pada masa kanak-kanak merupakan kegiatan keseharian sebagai dasar pembelajaran yang dilakukan setiap hari oleh anak secara alamiah untuk mengenali diri sendiri, lingkungan serta untuk mengembangkan setiap aspek perkembangan anak.

Permainan tradisional disebut juga permainan rakyat, merupakan permainan yang tumbuh dan berkembang pada masa lalu terutama tumbuh di masyarakat pedesaan (Yunus, 1981:56). Permainan tumbuh dan berkembang berdasarkan kebutuhan 
masyarakat setempat. Kebanyakan permainan tradisional dipengaruhi oleh alam sekitarnya sehingga menarik, menghibur sesuai dengan kondisi masyarakat saat itu. Nilai-nilai budaya yang terkandung dalam permainan tradisional antara lain: melatih sikap mandiri, berani mengambil keputusan, penuh tanggung jawab, jujur, sikap dikontrol oleh lawan, kerjasama, saling membantu dan saling menjaga, menjaga kepentingan kelompok, berjiwa demokrasi, petuh terhadap peraturan, penuh perhitungan, ketepatan, berpikir dan bertindak, tidak cengeng, berani, bertindak sopan, dan bertindak luwes (Ismail, 2006:106).

Karakteristik permainan tradisional yaitu menggunakan bahan alam sekitar sebagai sumber bermain dan sumber alat permainan yang didukung kemampuan dan kreativitas dalam menggunakan bahan yang ada di lingkungan sekitar menjadi alat permainan. Permainan tradisional dimainkan secara bersamaan atau kelompok. kekuatan dari bermain permainan tradisional, yaitu: mengutamakan interaksi sosial yang mengutamakan kerjasama, kekompakan, saling asah, asih, asuh dan melatih emosi serta moral anak kareena dalam proses bermain anak dituntut untuk bermain jujur, adil dan penuh tanggung jawab. Permainan tradisional memiliki nilai-nilai luhur dan pesan moral seperti: nilai kebersamaan, kejujuran, tanggung jawab. lapang dada (kalau kalah), dorongan berprestasi, menghargai orang lain, keakraban, toleransi, aktif, kratif, kemadirian, kepedulian terhadap lingkungan sekitar, solidaritas, sportivitas dan taat pada aturan. Permainan tradisional memiliki sifat fleksibel, yaitu dapat dimainkan di dalam ruangan maupun di luar ruangan. Peraturan dalam permainan tradisional dapat disesuaikan dengan kesepakatan para pemain.

\section{METODE}

Penelitian ini menggunakan metode penelitian tindakan (Action Research). Tujuan penelitian tindaka ini adalah untuk meningkatkan kecerdasan intrapersonal anak usia dini. Penelitian ini dirancang dalam beberapa tahapan. Penelitian ini dilakukan dengan menggunakan siklus, setiap siklus mempunyai empat kegiatan utama yang terdiri atas perencanaan, tindakan, pengamatan, dan refleksi.

Penelitian ini menganalisis cara peningkatan kecerdasan intrapersonal melalui permainan tradisional di TK Mardi Putra 03 Desa Sumber Brantas, Kecamatan Bumiaji Kota Batu-Malang. Subjek penelitian ini adalah peserta didik kelompok A Tahun pelajaran 2017/2018 dengan jumlah 15 anak dimana 7 anak laki-laki dan 8 anak perempuan. Permainan tradisional dilakukan secara bertahap sesuai dengan prosedur yang ada. terdapat dua siklus dalam penelitian ini, setiap siklus dilakukan 5 kali pertemuan.

Instrumen pengumpulan data yang digunakan dalam penelitian tindakan ini adalah observasi, catatan lapangan, wawancara dan dokumentasi penelitian. Peneliti mendiskusikan dengan kepala sekolah dan kolaborator untuk mengadakan perbaikan dan melanjutkan tindakan pada siklus II untuk mencapai keberhasilan. Penelitian ini mengacu pada desain penelitian Kurt Lewin.

\section{HASIL DAN PEMBAHASAN}

Berdasarkan hasil penelitian diketahui bahwa rata-rata perolehan nilai kecerdasan intrapersonal sebelum tindakan diberikan hasil prosentase yang diperoleh adalah 38,9\%. Data awal peningkatan kecerdasan intrapersonal meliputi aspek mengenal perasaan diri sendiri, mengenal kemampuan dan kelemahan diri sendiri, bersikap realistis terhadap kelemahan dan kelebihan diri sendiri, berfikir reflektif dan mengekspresikan perasaan cukup rendah. Hasil prapenelitian kecerdasan intrapersonal anak masih rendah, hal ini terlihat pada saat pada saat anak melihat perbedaan dan persamaan 
dirinya dengan orang lain, anak lemah dalam mengidentifikasi emosi diri sendiri seperti menyatakan bahwa mereka senang, sedih, belum berani menentukan kegiatan apa yang dilakukan sendiri, belum paham untuk menerima kekurangan dan kelebihan diri sendiri, belum begitu terlihat pengalihan pemikiran imajinatif pada kenyataan, kemampuan untuk melakukan sesuatu kegiatan masih belum nampak, kemampuan memandang dunia dari sudut diri sendiri masih rendah dan mengontrol perilaku diri sendiripun juga masih rendah. Pada saat mengontrol perilaku diri sendiri anak cenderung selalu melihat respon orang lain, anak tidak berani memutuskan saya akan bermain apa, dengan siapa dan permainan yang bagaimana.

Setelah dilakukan tindakan pada siklus satu diperoleh hasil $61,24 \%$. Kecerdasan intrapersonal pada tindakan di siklus satu meliputi aspek: mengenal perasaan diri sendiri, mengenal kemampuan dan kelemahan diri sendiri, bersikap realistis terhadap kelemahan dan kelebihan diri sendiri, berfikir reflektif dan mengekspresikan perasaan dengan tepat. Setelah ditrapkan aktivitas permainan tradisional dalam meningkatkan kecerdasan intrapesonal terlihat bahwa setelah dilakukan tindakan pada siklus satu sebagian besar anak sudah mampu memahami dirinya dan mulai menerapkan kemunculan sikap mengenal perasaan diri sendiri, mengenal kemampuan dan kelemahan diri sendiri, bersikap realistis terhadap kelemahan dan kelebihan diri sendiri, berfikir reflektif dan mengekspresikan perasaan dengan tepat. Hal ini dikarenakan permainan tradisional pada saat uji coba antusias anak-anak sangat tinggi. Hal ini diketahui ketika anak bermain permainan jamuran, cublak-cublak suwong, lompat tali dan permainan petak umpet nampak anak-anak senang, antusias anak tinggi dana minat anak untuk mecoba sangat tinggi sekali.

Pada siklus dua terjadi peningkatan menjadi $82,13 \%$ dengan nilai pada masingmasing aspek sebagai berikut: mengenal perasaan diri sendiri mencapai $65,25 \%$, mengenal kemampuan dan kelemahan diri sendiri mencapai skor $65,25 \%$, kemampuan mengnal kelemahan diri sendiri mencapai $66,5 \%$, bersikap realistis terhadap kekuatan dan kelemahan diri sendiri mencapai $66,5 \%$, berfikir reflektif mencapai $65,14 \%$ dan mengekspresikan perasaan dengan tepat mencapai skor $67 \%$.

\section{SIMPULAN}

Berdasarkan paparan di atas dapat ditarik kesimpulan bahwa pelaksanaan kegiatan pembelajaran untuk meningkatkan kecerdasan intrapersonal anak melalui permainan tradisional pada anak kelompok B dinilai efektif. Hal ini diketahui berdasarkan hasil penelitian yang telah dilakukan bahwa terjadi peningkatan proses pembelajaran baik secara proses dan hasil. Secara kuantitatif dapat diketahu kenaikan hasil pembelajaran yairu pada prasiklus hasil prosentase pembelajaran anak berada pada angka 38,9\%, kemudian pada siklus satu penelitian terjadi peningkatan yang cukup signifikan yaitu $61,24 \%$ dan pada siklus dua terjadi peningkatan sebesar $82.13 \%$.

\section{DAFTAR PUSTAKA}

Amstrong, T. 2009. Multiple Intellegencs in the classroom. USA Virginia, Alexandria: ASCD Association and Curriculum Development.

Gardner, H. 1993. Frames Of Maind The Theory of Mulitple Intellegences tenth anniversary edition. New york: Perseus of Books Group.

Hartati. S. 2007. How To Be a Good Teacher and To Be a Good Mother. Jakarta: Enno Media.

Hoerr, T. 2007. Buku Kerja Multiple Intellegences. Bandung: Mizan Pustaka 
Musfiroh, T. 2008. Cerdas Melalui Bermain. Cara mengasuh Multiple Intellegences. Jakarta: Grasindo.

Ramli. 2004. Pendampingan Perkembangan Anak Usia Dini. Jakarta: Depdiknas.

Suyadi. 2004. Teori Pembelajaran Anak Usia Dini. Bandung: Remaja Rosdakarya.

Undang-undang Nomor 20 tahun 2003 tentang Sisdiknas, Pasal 28 ayat 1 